\title{
Effect of water stress on nitrogen fixation and nodule structure of common bean ${ }^{(1)}$
}

\author{
Maria Lucrecia Gerosa Ramos ${ }^{(2)}$, Richard Parsons ${ }^{(3)}$, Janet Irene Sprent ${ }^{(3)}$ \\ and Euan Kelvin James ${ }^{(3)}$
}

\begin{abstract}
The aim of this work was to investigate the effect of water stress on $\mathrm{N}_{2}$ fixation and nodule structure of two common bean (Phaseolus vulgaris L.) cultivars Carioca and EMGOPA-201. Plants were harvested after five and eight days of water stress. Carioca had lower nodule dry weight on both water stress periods; shoot dry weight was lower at five days water stress and did not differ from control after eight days stress. Both cultivars had lower nitrogenase activity than control after five and eight days water stress. For both cultivars, after eight days stress bacteroid membranes were damaged. Carioca presented more pronounced damage to infected tissue, with host cell vacuolation and loss of the peribacteroid membrane at five days after stress; at eight days after stress, there was degradation of cytoplasm host cells and senescence of bacteroids, with their release into intercellular spaces. Intensity of immunogold-labeling of intercellular cortical glycoprotein with the monoclonal antibodies MAC 236/ 265 was different for both cultivars.
\end{abstract}

Index terms: Phaseolus vulgaris, nitrogenase, leaf water potential, nodulation.

Efeito do estresse hídrico na fixação biológica de nitrogênio e estrutura de nódulos de feijão

Resumo - O objetivo deste trabalho foi investigar o efeito do estresse hídrico na fixação biológica do $\mathrm{N}_{2}$ e na estrutura dos nódulos de feijão (Phaseolus vulgaris L.), nas cultivares Carioca e EMGOPA-201. As plantas foram colhidas após cinco e oito dias de estresse hídrico. A cultivar Carioca apresentou menor peso seco de nódulos que o controle (plantas irrigadas). O peso da parte aérea seca da cultivar Carioca foi menor aos cinco dias de estresse hídrico e não diferiu do controle, após oito dias de estresse. As duas cultivares tiveram menor atividade da nitrogenase após cinco e oito dias de estresse hídrico e apresentaram danos na membrana peribacteróide após oito dias de estresse. A cultivar Carioca foi mais afetada do que a EMGOPA-201, com vacuolação das células e perda da membrana peribacteróide após cinco dias de estresse; aos oito dias, houve degradação das células do citoplasma, senescência e liberação dos bacteróides nos espaços intercelulares. A intensidade de glicoproteínas nos espaços intercelulares do córtex, marcada com os anticorpos MAC 236/265, foi diferente nas duas cultivares de feijão.

Termos para indexação: Phaseolus vulgaris, nitrogenase, potencial de água na folha, nodulação.

\section{Introduction}

Common bean (Phaseolus vulgaris L.) is the major source of protein in Latin America. This legume can associate with Rhizobium and fix atmospheric N, leading to lower production costs and decreasing problems of pollution caused by $\mathrm{N}$ fertilizers, such as nitrate. However, there are several factors affecting its performance in tropical conditions, such as high

\footnotetext{
(1) Accepted for publication on July 19, 2002.

(2) Universidade de Brasília, Fac. de Agronomia e Medicina Veterinária, Caixa Postal 04508, CEP 70910-970 Brasília, DF. E-mail: lucrecia@unb.br

(3) University of Dundee, Dundee, DD1 4HN, UK.
}

temperatures (Ferrari et al., 1967), low soil pH (Ramos \& Boddey, 1987), Al toxicity (Franco \& Munns, 1982) and water availability (Ramos et al., 1999).

Factors affecting plant development can alter the formation and growth of nodules. A decrease in soil water potential can markedly affect root hair (Worral \& Roughley, 1976) and retard nodule growth (Gallacher \& Sprent, 1978) and $\mathrm{N}_{2}$ fixation (Ramos et al., 1999). Once nodules are formed, water stress can also lead to morphological and physiological alterations. Guerin et al. (1990) observed in Vicia faba alterations in cell shape in the cortex where cells were densely packed, leading to reduction in air spaces and subsequent reduction of $\mathrm{O}_{2}$ diffusion barrier to the central tissue. 
Although there are several publications showing changes in nodule structure in plants under salt stress (Serraj et al., 1995), there is little information about the effects of drought on legume nodule structure.

Common bean cultivars vary in tolerance to water stress. Out of seven cultivars studied by Pimentel et al. (1990), two were tolerant to water stress, and had the same productivity with or without stress.

The aim of this work was to investigate the effects of water stress on nitrogen fixation and nodule structure of two common bean cultivars.

\section{Material and Methods}

Seeds of cultivars EMGOPA-201 and Carioca of common bean (Phaseolus vulgaris L.) were surface sterilized in $80 \%$ ethanol for 30 seconds, $5 \%$ sodium hypochlorite for two minutes and washed ten times in sterilized distilled water. Seeds were pre-germinated in Petri dishes with wet filter paper for two days. After this period the seeds were transferred to pots with a mixture of washed vermiculite and perlite $(1: 1 \mathrm{v} / \mathrm{v})$ and inoculated with $1 \mathrm{~cm}^{3}$ of a mixture of two effective strains of Rhizobium (Rhizobium leguminosarum bv. phaseoli - strain BR 353 and Rhizobium tropici - strain BR 322). These strains are efficient on $\mathrm{N}_{2}$ fixation.

The experiment was arranged in a four randomized blocks design and a factorial scheme 2x2x2, with two cultivars, two levels of water stress and two controls for each stress.

Plants were grown in a mixture of sand and vermiculite (1:1) in a growth chamber with 14 -hour photoperiod, which emitted a quantum irradiance of $700 \mu \mathrm{mol}$ photons $\mathrm{m}^{-2} \mathrm{~s}^{-1}$, day/night temperatures of $24^{\circ} \mathrm{C}$ and $16^{\circ} \mathrm{C}$, respectively, and relative humidity of approximately $50 \%$. The macronutrient solution composition (Summerfield et al., 1977) was in mg dm${ }^{-3}: \mathrm{CaSO}_{4}, 500 ; \mathrm{MgSO}_{4} .7 \mathrm{H}_{2} \mathrm{O}, 275$; $\mathrm{K}_{2} \mathrm{HPO}_{4}, 175$; NaFeEDTA, 41; $\mathrm{K}_{2} \mathrm{SO}_{4}, 169$. The micronutrient solution was in $\mathrm{g} \mathrm{dm}^{-3}: \mathrm{KCl}, 13.5 ; \mathrm{H}_{3} \mathrm{BO}_{3}$, 15; $\mathrm{MnSO}_{4} . \mathrm{H}_{2} \mathrm{O}$, 8.5; $\mathrm{ZnSO}_{4} .7 \mathrm{H}_{2} \mathrm{O}, 1.35 ; \mathrm{CuSO}_{4} .5 \mathrm{H}_{2} \mathrm{O}$, 1.2 and $\mathrm{MoO}_{3}, 11.18$. A stock nutrient solution was added at $0.2 \mathrm{~cm}^{3} \mathrm{dm}^{-3}$.

Plants were kept at field capacity for 24 days before the stress treatments were started. Water was withheld from half of the plants which were harvested after five and eight days of water stress. There was a parallel control watered for each harvest. After being harvested, plants were dried at $65^{\circ} \mathrm{C}$ and grounded for determination of $\mathrm{N}$ concentration, using a Analyzer (Model 1106). Leaf water potential (LWP) was measured in the youngest fully most expanded leaf, using a pressure bomb (Scholander et al., 1965). Relative water content was measured in one leaflet just below the youngest expanded leaf. The relative water content per cent (RWC) was determined through the following equation:

RWC $=($ FW-DW $) /($ SW-DW $) \times 100$

where FW: fresh weight; DW: dry weight; SW: shoot weight. Acetylene reduction was measured in an open flow system, following the procedure of Minchin et al. (1983).

Fresh nodules were excised from the root, cut in half and fixed in $2.5 \%$ glutaraldehyde in $50 \mathrm{mmol} \mathrm{dm}^{-3}$ potassium phosphate buffer, $\mathrm{pH} 6.8$, at $4^{\circ} \mathrm{C}$. Specimens were rinsed in the same buffer and half of them were postfixed for two hours in $0.2 \%$ osmium tetroxide. After washing with the same buffer, nodules were dehydrated in an ethanol series and placed in LR White Acrylic resin on a specimen rotator at $120 \mathrm{rpm}$ for seven days at $40^{\circ} \mathrm{C}$. Specimens were transferred to an oven at $60^{\circ} \mathrm{C}$ to polymerize the resin.

Sections were cut on a Reichert Om V3 microtome $(1 \mu \mathrm{m})$, stained with $33 \mathrm{mmol} \mathrm{dm}^{-3}$ toluidine blue in $162 \mathrm{mmol} \mathrm{dm}^{-3}$ sodium tetraborate and examined using an light microscope.

From nodule pieces $(1 \mathrm{~mm})$ treated with osmium, ultrathin sections were cut with a glass or diamond knife on a Reichert Om V3 microtome and collected on copper grids. Sections were stained with uranyl acetate for $30 \mathrm{~min}$, then transferred to drops of lead citrate for ten minutes. They were examined using a $1200 \mathrm{EX}$ transmission electron microscope.

Thin sections $(90 \mathrm{~nm})$ were processed according to Bradley et al. (1988) and James (1990). They were collected on pyroxylin, carbon-coated nickel grids and incubated for one hour at room temperature on drops of blocking buffer, consisting of bovine serum albumin in Tris-HCl, $\mathrm{pH}$ 7.5; $0.9 \%(\mathrm{w} / \mathrm{v})$ sodium chloride; $0.5 \mathrm{mg} \mathrm{cm}^{-3}$ polyethylene glycol - 20kD; $0.02 \%(\mathrm{w} / \mathrm{v})$ sodium azide to prevent non specific binding on the antibodies. The grids were washed in distilled water and then transferred to $50 \mathrm{~mm}^{3}$ drops of primary antibody (MAC 236, MAC 265) diluted 1:100 in blocking buffer and incubated at $4^{\circ} \mathrm{C}$ for 8-16 hours. The grids were washed with distilled water and placed on $25 \mathrm{~mm}^{3}$ drops of the secondary antibody (goat anti-rat antibodies conjugated to $10 \mathrm{~nm}$ gold particles, diluted 1:100 in blocking buffer and kept at room temperature for 1-2 hours. The grids were washed in two drops of blocking buffer containing 1\% T-20. Finally, they were post-stained in $2 \%$ uranyl acetate for ten minutes and in Reynolds lead citrate for two minutes and examined in a 1200 EX transmission electron microscope. The irrelevant antibody MAC 83 was substituted for the primary 
antibodies MAC 236 and MAC 265 as a control for non-specific labeling (Vandenbosch et al., 1994).

\section{Results and Discussion}

Carioca shoots grew almost twice as much as those of EMGOPA-201. Watered plants at the second harvest (control) showed higher $\mathrm{N}$ accumulation and nitrogenase activity than those from the first harvest (control), suggesting that plants were fixing and accumulating nitrogen (Table 1). Carioca shoot dry weight decreased $16 \%$ after five days without water. After eight days, there was still a trend of lower values for shoot dry weight, but they did not differ statistically from the control. Shoot dry weight of EMGOPA-201 was not affected by stress.

Carioca shoots had lower $\mathrm{N}$ uptake after five and eight days of water stress and decreases were $25 \%$ and $40 \%$, compared to respective controls (Table 1). For EMGOPA-201, there was no significant difference between the controls and stress levels for this parameter.

In general, EMGOPA-201 had lower nodule fresh and dry weights than Carioca (Table 1). Although nodule fresh weight was similar in Carioca watered on both harvests, nitrogenase activity was higher at eight days, suggesting an improvement in nitrogen fixation. Nodule fresh weight was lower on both levels of stress for Carioca, with decreases of $52 \%$ and $60 \%$ for five and eight day stresses, respectively (Table 1). Saito et al. (1984) also observed a sharp decrease in nodule fresh weight for cultivar Carioca under two levels of water stress. Nodule fresh weight in EMGOPA-201 was not affected by stress treatment. Nodule dry weight decreased by 33\% and 35\% in relation to the respective controls, for cultivar Carioca and did not change for EMGOPA-201 at any level of stress (Table 1).

Specific nitrogenase activity was always lower under water stress on both cultivars (Table 1). Moisture greatly affects nitrogenase activity in legumes and in situations of extreme stress, nitrogenase activity ceases (Guerin et al., 1990). Even a mild stress (drop in leaf water potential of -0.4 MPa) can significantly reduce nitrogenase activity in legumes (Rao \& Venkateswarlu, 1987). A decrease in nitrogenase activity leads to low production of ammonia and to a decrease in ammonia-assimilating enzymes under water stress (Kaur et al., 1985).

Table 1. Shoot dry weight (SDW), total N on shoot (N), nodule fresh weight (NFW), nodule dry weight (NDW) and specific nitrogenase activity (SNA) of two common bean cultivars under two water stress periods ${ }^{(1)}$.

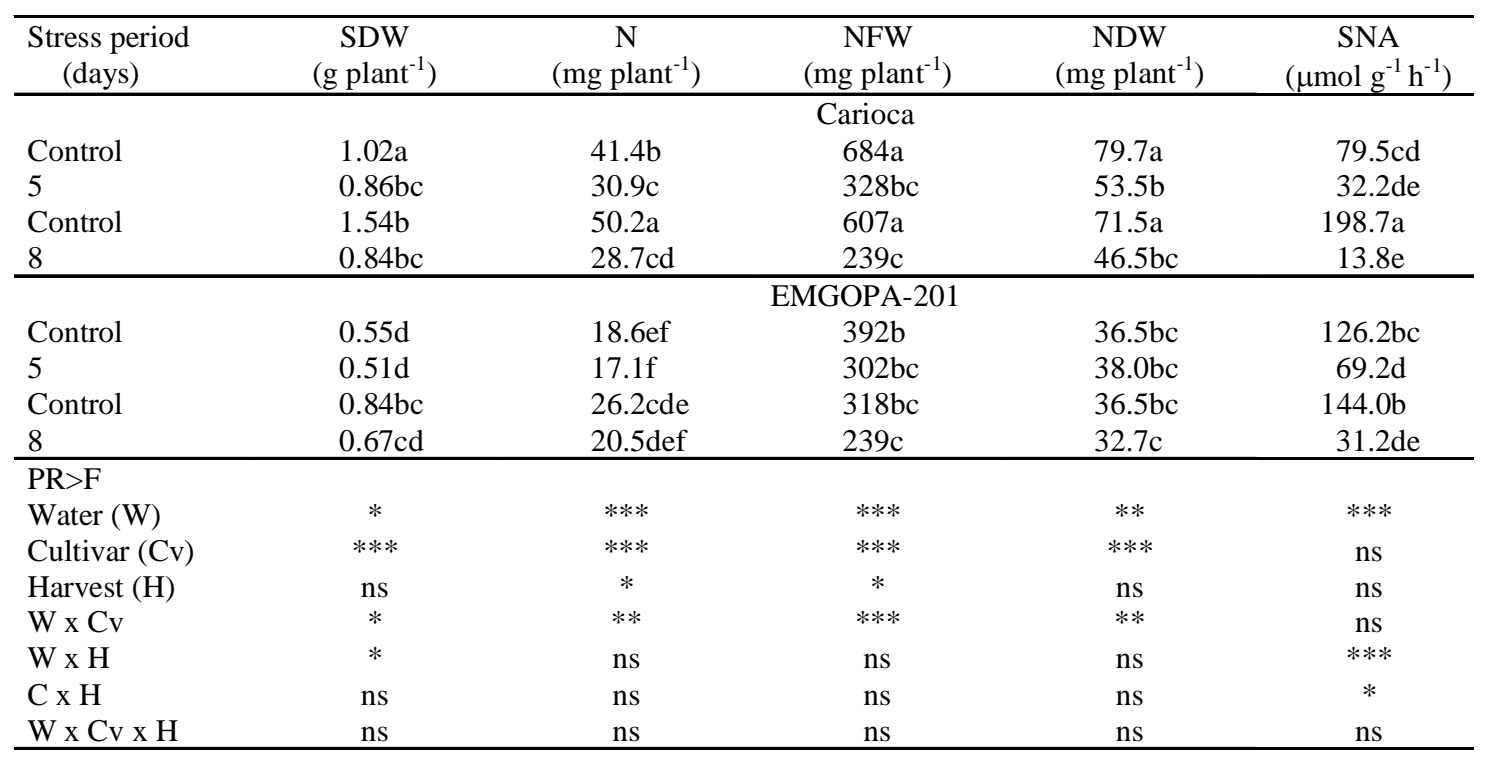

(1)Numbers followed by the same letter in each column do not differ statistically by the Duncan's test at $5 \%$ probability level; data are means of four

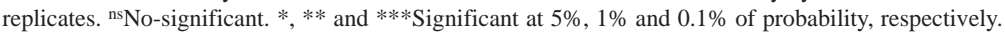


Leaf water potential was similar for all controls on both cultivars, however during the period of stress, cultivar Carioca showed lower levels than EMGOPA-201 on both levels of water stress (five and eight days) (Table 2).

Relative water content in leaves was similar for EMGOPA-201 in all treatments but differed statistically from the controls for Carioca (Table 2). Although the correlation between LWP and relative water content had a low $\mathrm{R}^{2}(0.62)$, RWC results suggest that stress effect was higher in Carioca than in EMGOPA-201 (Table 2). As a consequence, Carioca was more affected at eight days than EMGOPA-201, with a sharp decrease in nodule fresh weight (loss of $60 \%$ ) and very low levels of nitrogenase activity. Shoot and nodule dry weights of EMGOPA-201 were not affected by stress, but nitrogenase activity decreased sharply, mainly at eight days of water stress.

Root nodules from both cultivars which were watered had several layers of cells in the lenticels (Figure 1a). The outer cortex had approximately two layers of large and compacted cells with deposits of dark-staining material in the intercellular spaces. Cells were progressively smaller from the middle and inner cortex; there were 1-2 layers of small and interlocking cells, which are analogous to the boundary layer, described by Parsons \& Day (1990) for soybean. Few electron-transparent inclusions, presumably poly- $\beta$-hydroxybutyrate (PHB), could be seen in the

Table 2. Leaf water potential (LWP) and relative water content (RWC) of two common bean cultivars, under water stress $^{(1)}$.

\begin{tabular}{lrc}
\hline Stress period (days) & LWP (Bar) & RWC \\
\hline \multirow{2}{*}{ Control } & \multicolumn{2}{c}{ Carioca } \\
5 & $-4.95 \mathrm{~d}$ & $91.83 \mathrm{a}$ \\
Control & $-8.85 \mathrm{~b}$ & $86.66 \mathrm{~b}$ \\
8 & $-4.47 \mathrm{~d}$ & $94.02 \mathrm{a}$ \\
\hline \multicolumn{3}{c}{ EMGOPA-201 } \\
Control & $-10.55 \mathrm{a}$ & $81.33 \mathrm{c}$ \\
5 & $-4.65 \mathrm{~d}$ & $96.76 \mathrm{a}$ \\
Control & $-6.32 \mathrm{c}$ & $93.59 \mathrm{a}$ \\
8 & $-4.27 \mathrm{~d}$ & $94.15 \mathrm{a}$ \\
\hline
\end{tabular}

(1)Numbers followed by the same letter in each column do not differ statistically by Duncan's test at $5 \%$ of probability; data are means of four replicates. bacteroids (Figure 2a). There were numerous intercellular spaces in the infected tissue and most appeared not to be occluded (Figure 3a).

Consistent with the growth data (Table 1), the structure of nodules from cultivar Carioca was more

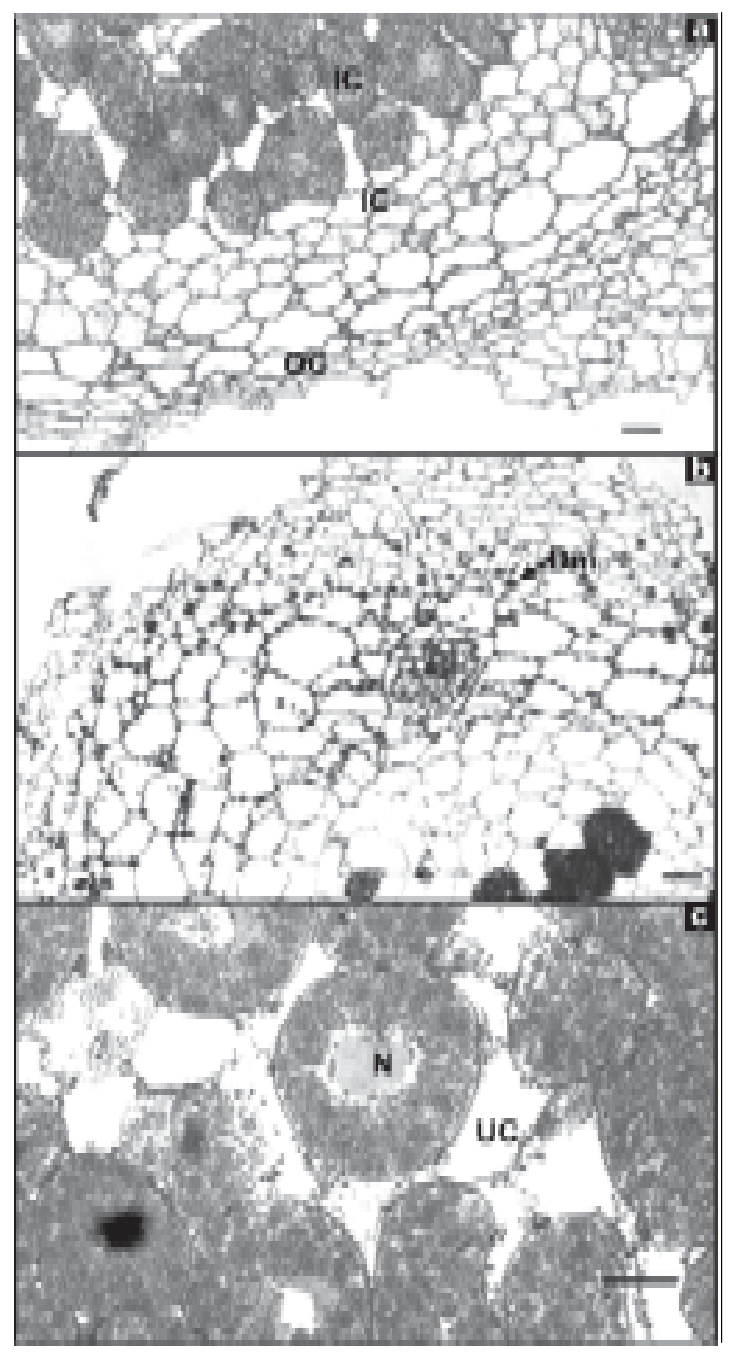

Figure 1. Light micrograph of nodule from cultivar EMGOPA-201 watered (a) showing lenticels and inner and outer cortex; after five days of water stress (b) showing a dark-staining material (dm) in lenticels, middle cortex and outer cortex and after five days of water stress (c), showing infected cells (UC) with nuclei (N). Bar $=25 \mu \mathrm{m}$ (a and c) and Bar $=50 \mu \mathrm{m}$ (b). 
affected by water stress than EMGOPA-201. For EMGOPA-201, at five days of water stress, in the lenticels, outer cortex, pericycle cells and vascular bundles, a dark staining material can be seen within the cells (Figure 1b). James et al. (1993) and Serraj et al. (1995) also found a dark-staining material in the cortex of soybean under salt stress. In the middle cortex, cell walls appear convoluted (Figure 1b). Nuclei can be seen in the infected cells (Figure 1c). However, peribacteroid membranes appear ruptured (Figure 3b). More inclusions of PHB are found within the bacteroid for Carioca (Figure 2b). For cultivar EMGOPA-201, some material was released into the intercellular spaces of the infected tissue, but bacteroids were not found in the spaces (Figure 3b)

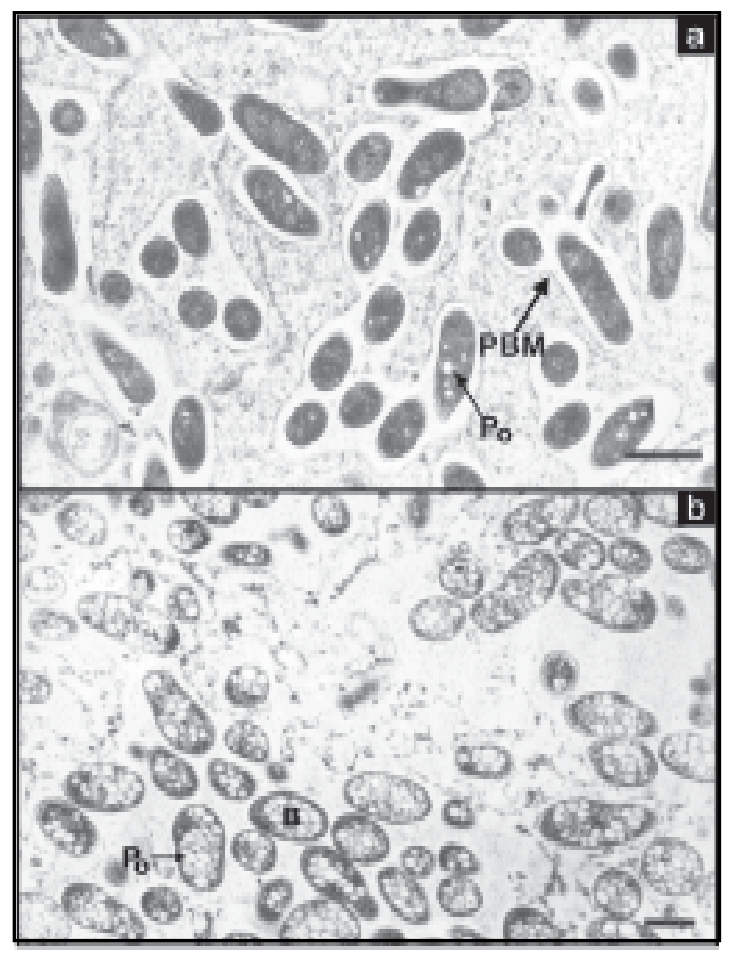

Figure 2. Transmission electron micrograph, showing inclusions of PHB in a nodule from cultivar EMGOPA-201 (a) watered, with peribacteroid membrane (PBM), PHB granules (Po) and from cultivar Carioca (b), after five days of water stress, showing rupture of peribacteroid membrane, bacteroid (B) and PHB granules (Po). Bar $=1 \mu \mathrm{m}$. and few inclusions of PHB are visible within the bacteroids (Figures 3b and 4a).

For EMGOPA-201, at eight days of water stress, fewer lenticels were found and a dark-staining material was not observed in any part of the cortex, suggesting that the material was metabolized by the cells

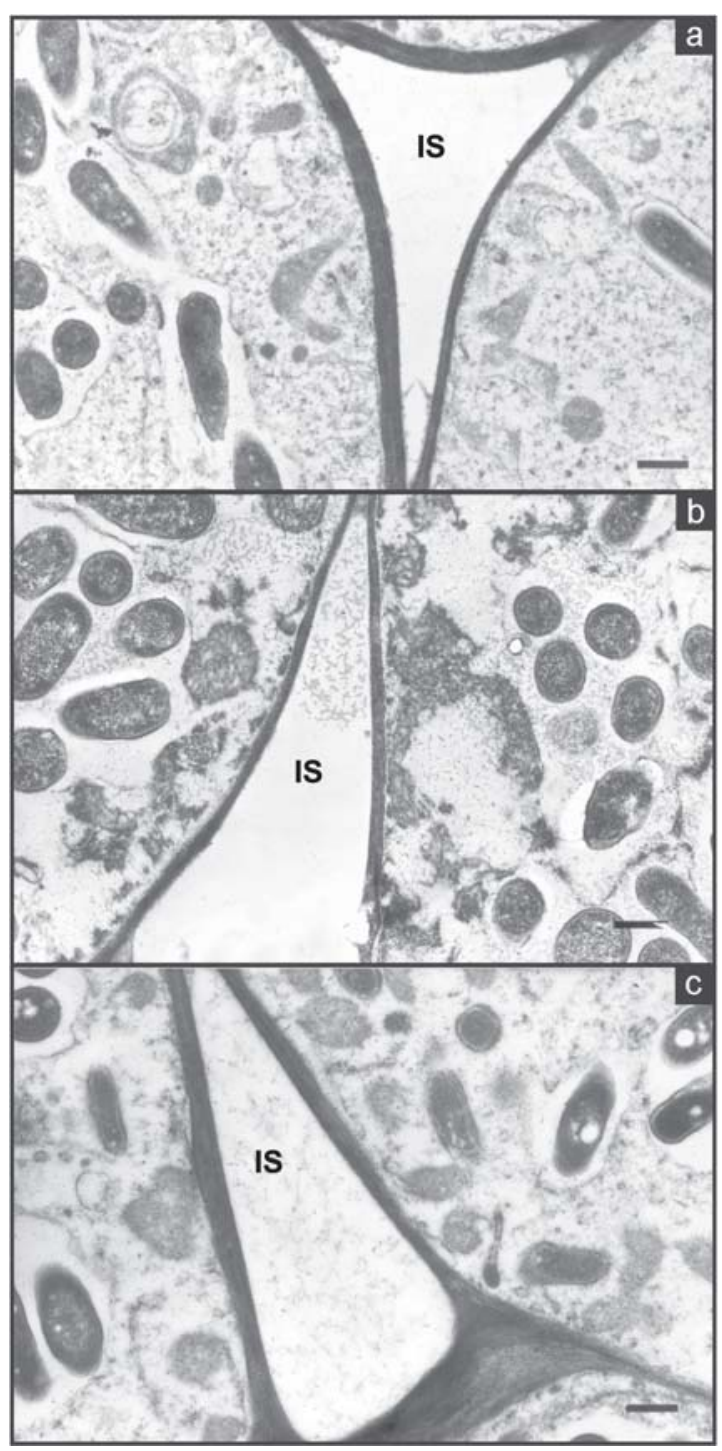

Figure 3. Transmission electron micrograph showing intercellular spaces (IS) in infected cells of a nodule from cultivar EMGOPA-201 watered (a) at five days of water stress (b) and at eight days of water stress (c). Bar $=500 \mathrm{~nm}$.

Pesq. agropec. bras., Brasília, v. 38, n. 3, p. 339-347, mar. 2003 
(Figure 4c). Cells from all parts of the cortex appeared flaccid and tightly compacted, with intercellular

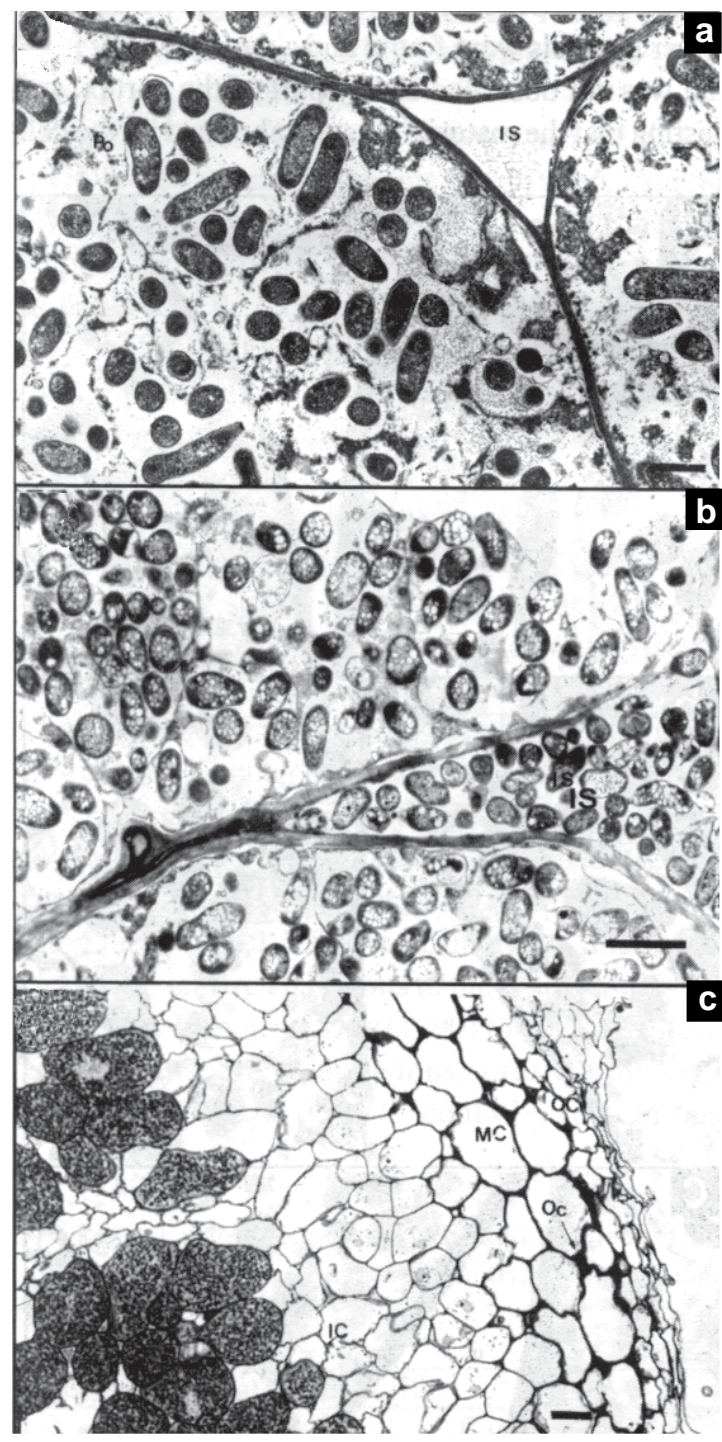

Figure 4. Transmission electron micrograph showing inclusions of $\mathrm{PBH}$ and a rupture of peribacteroid membrane (PBM) of a nodule from cultivar EMGOPA-201 at five days of water stress (a); cultivar Carioca after eight days of water stress (b), showing bacteroids free in the infected cells, without any apparent membrane and intercellular spaces (IS) filled with bacteroids and cultivar EMGOPA-201 after eight days of water stress (c), showing outer cortex (OC), cytoplasmic degradation in the inner (IC) and middle cortex (MC). Bar = $1 \mathrm{~mm}$ (a), Bar = $2 \mathrm{~mm}$ (b), Bar $=25 \mathrm{~mm}$ (c). spaces occluded. Compared with other treatments, more inclusions of PHB are found for EMGOPA-201 (Figure 4a) and for Carioca (Figure 4b). Peribacteroid membranes were ruptured and a release of material was observed in the intercellular spaces of Carioca which are filled with bacteria (Figure 4b). Water stress is not the only kind of stress which can lead to a release of bacteroids in the intercellular spaces. Common bean grown at high levels of $\mathrm{Al}$ in the nutrient solution (Jacob-Neto, 1993) and soybean nodules under salt stress (James et al., 1993) also showed a release of bacteroids in intercellular spaces of infected cells.

For both cultivars, an increase of water stress led to an increase of inclusions of PHB. It is suggested by Bergersen \& Turner (1992) that PHB can be utilized by the nodules during periods of limited supply of photosynthates. Also, PHB builds up in bacteroids when the concentration of free dissolved $\mathrm{O}_{2}$ is low (Bergersen \& Turner, 1990).

Immunogold labeling, using the monoclonal antibodies MAC 236/265 (Vandenbosch et al., 1994) was used to detect the presence of glycoprotein in the intercellular spaces of the cortex and infected tissue of the two cultivars. Intercellular spaces of watered plants on both cultivars were gold-labeled with MAC 236 (Figures 5a and 6a), but labeling was more intense in EMGOPA-201. After five days of stress, EMGOPA-201 had only a few gold particles in the intercellular spaces (Figure 5b).

After eight days of stress, gold particles were not found in intercellular spaces in EMGOPA-201 (Figure 5c), but in Carioca intercellular spaces contained many gold particles (Figure 6b). These results suggest that levels of glycoprotein recognized by the antibody MAC 236 can increase for cultivar Carioca or decrease for EMGOPA-201 during stress treatments. It is not known which mechanisms are involved to produce different levels of glycoprotein on stressed plants.

Immunogold labeling for the monoclonal antibody MAC 265 was found only in EMGOPA-201 control nodules. Labelling was seen in intercellular spaces in infected tissue (Figure 6c), suggesting that glycoprotein also occurs in other parts than the nodule cortex. 
The fact that different responses of immunolabeling of intercellular spaces occurred in the studied cultivars could suggest that compounds other than glycoproteins are also present in the occluded intercellular spaces. Several compounds, such
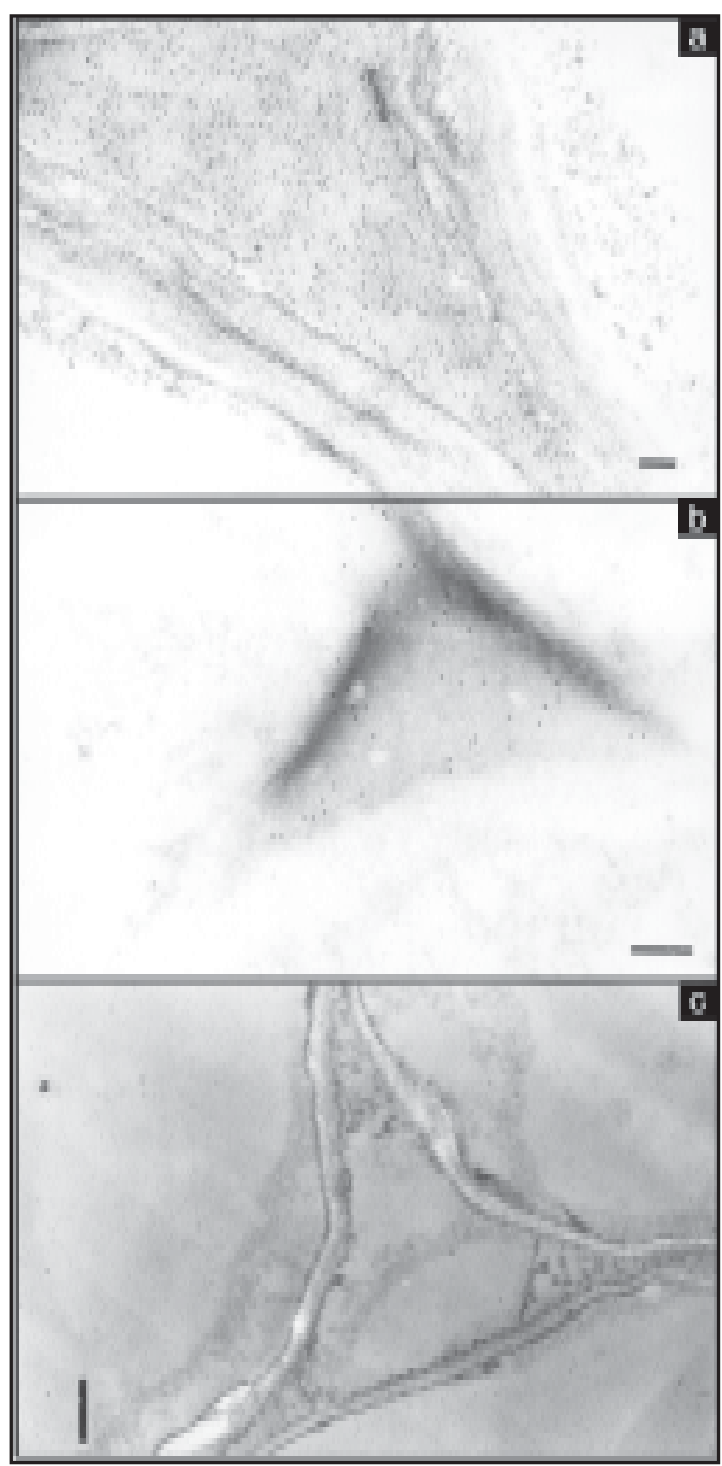

Figure 5. Gold-labeling of the intercellular space using MAC 236 in EMGOPA-201 watered (a), at five days of water stress (b) and at eight days of water stress (c). Bar $=200 \mathrm{~nm}$ (a and b), Bar $=500 \mathrm{~nm}$ (c). as hydroxy-proline rich proteins (Sherrier \& Vandenbosh, 1994), lectins (Vandenbosch et al., 1994) and diprenylated isoflavones (Grandmaison \& Ibrahim, 1995), have been observed in this nodule region.

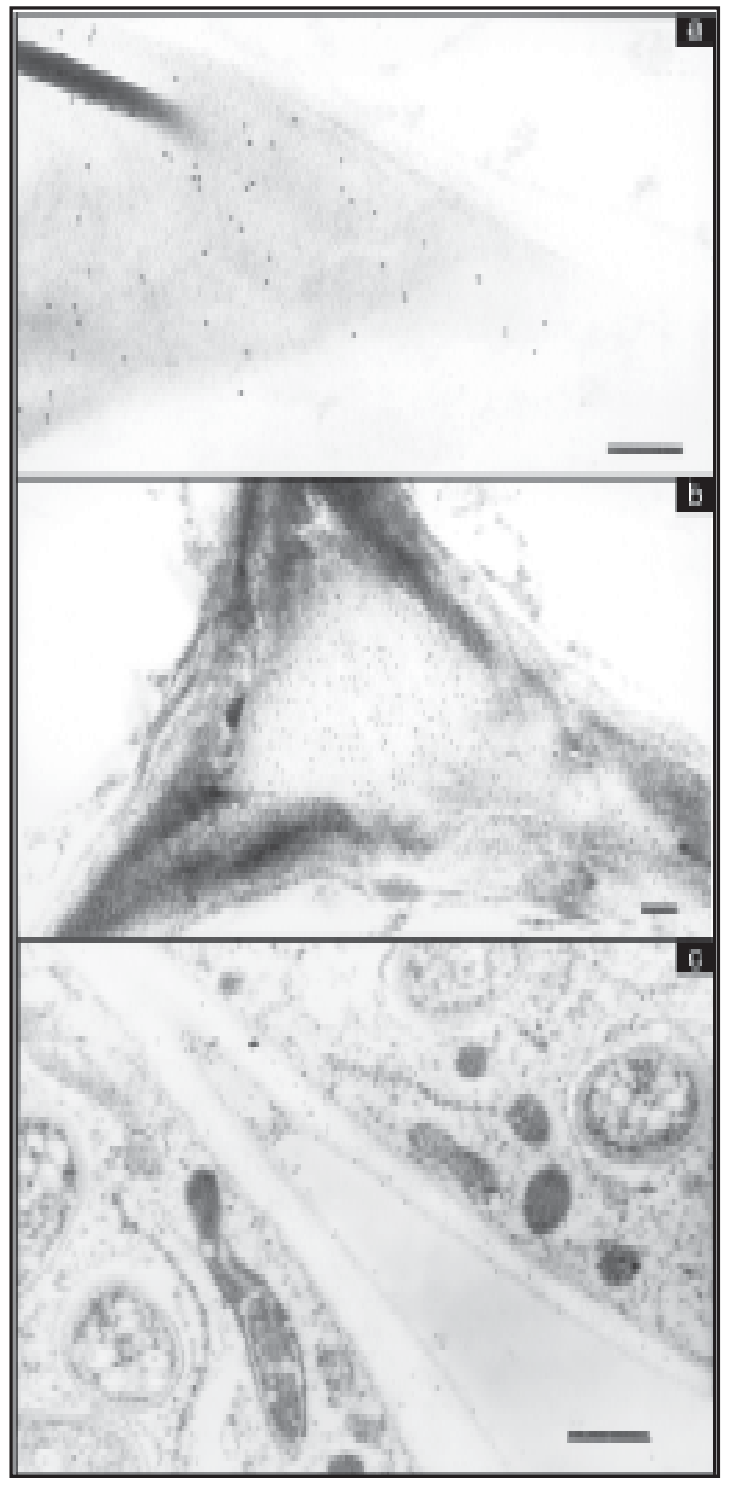

Figure 6. Gold-labeling of the intercellular space using MAC 236 in Carioca watered (a); at eight days of water stress (b) and gold-labeling of the intercellular space in infected cells, using MAC 265 in EMGOPA-201 watered (c). Bar $=200 \mathrm{~nm}$ (a and b); Bar = $500 \mathrm{~nm}$ (c).

Pesq. agropec. bras., Brasília, v. 38, n. 3, p. 339-347, mar. 2003 


\section{Conclusions}

1. Detrimental effect of water stress is higher in cultivar Carioca than in EMGOPA-201.

2 . Both cultivars show very low nitrogenase activity, mainly under eight days of water stress.

3. Water stress alters cultivars nodule structure and intercellular glycoprotein content.

\section{Acknowledgements}

To Martin Kierans, for technical assistance and to CNPq, for financial support.

\section{References}

BERGERSEN, F. J.; TURNER, G. L. Bacteroids from soybean root nodules: accumulation of poly- $\beta$-hydroxybutyrate during supply of malate and succinate in relation of $\mathrm{N}_{2}$-fixation in flow-chamber reactions. Proceedings of the Royal Society of London B, London, v. 240, p. 39-59, 1990.

BERGERSEN, F. J.; TURNER, G. L. Supply of $\mathrm{O}_{2}$ regulates $\mathrm{O}_{2}$ demand during utilization of reserves of poly- $\beta$-hydroxybutirate in $\mathrm{N}_{2}$-fixing soybean bacteroids. Proceedings of the Royal Society of London B, London, v. 249, p. 143-148, 1992.

BRADLEY, D. J.; WOOD, E. A.; LARKINS, A. P.; GALFRE, G.; BUTCHER, G. W.; BREWIN, N. J. Isolation of monoclonal antibodies reacting with peribacteroid membranes and other components of pea root nodules containing Rhizobium leguminosarum. Planta, Oxford, v. 173, p. 49-68, 1988.

FERRARI, E.; SOUTO, S. M.; DÖBEREINER, J. Efeito da temperatura do solo na nodulação e no desenvolvimento da soja perene (Glycine javanica L.). Pesquisa Agropecuária Brasileira, Rio de Janeiro, v. 2, p. 461-466, 1967.

FRANCO, A. A.; MUNNS, D. N. Nodulation and growth of Phaseolus vulgaris in solution culture. Plant and Soil, Dordrecht, v. 66, p. 149-160, 1982.

GALLACHER, A. E.; SPRENT, J. I. The effect of different water regimes on growth and nodule development of greenhouse-grown Vicia faba. Journal of Experimental Botany, London, v. 29, p. 413-423, 1978.

GRANDMAISON, J.; IBRAHIM, R. K. Ultrastructural localization of a diprenylated isoflavone in Rhizobium
lupini-Lupinus albus symbiotic association. Journal of Experimental Botany, Oxford, v. 46, p. 231-237, 1995.

GUERIN, V.; TRICHANT, J. C.; RIGAUD, J. Nitrogen fixation $\left(\mathrm{C}_{2} \mathrm{H}_{2}\right.$ reduction) by broad bean (Vicia faba L.) nodules and bacteroids under water-restricted conditions. Plant Physiology, Baltimore, v. 92, p. 595-601, 1990.

JACOB-NETO, J. The interaction of $\mathrm{H}^{+} / \mathrm{OH}^{-}$exchanges between roots and rhizosphere with plant nutrition and aluminium effects. 1993. 310 leaves. Thesis (Ph.D. in Soil Science) - University of Dundee, Dundee, 1993.

JAMES, E. K. Oxygen diffusion barriers in the root nodules of legumes. 1990. 280 leaves. Thesis (Ph.D. in Plant Physiology) - University of Dundee, Dundee, 1990.

JAMES, E. K.; SPRENT, J. I.; HAY, G. T.; MINCHIN, F. R. The effect of irradiance on the recovery of soybean nodules from sodium chloride-induced senescence. Journal of Experimental Botany, Oxford, v. 44, p. 997-1005, 1993.

KAUR, A.; SHEORAN, I. S.; SINGH, R. Effect of water stress on the enzymes of nitrogen metabolism in mung bean (Vigna radiata Wilczeck) nodules. Plant, Cell and Environment, Oxford, v. 8, p. 196-200, 1985.

MINCHIN, F. R.; WITTY, J. F.; SHEEHY, J. E.; MULLER, M. Major error in the acetylene reduction assay: decreases in nodular nitrogenase activity under assay conditions. Journal of Experimental Botany, Oxford, v. 34, p. 641-649, 1983.

PARSONS, R.; DAY, D. A. Mechanism of soybean nodule adaptation to different oxygen pressures. Plant, Cell and Environment, Oxford, v. 13, p. 501-512, 1990.

PIMENTEL, C.; JACOB-NETO, J.; GOI, S. R.; PESSANHA, G. G. Estresse hídrico em cultivares de Phaseolus vulgaris L. em simbiose com o Rhizobium leguminosarum biovar phaseoli. Turrialba, San José, v. 40, p. 520-526, 1990.

RAMOS, M. L. G.; BODDEY, R. M. Yield and nodulation of Phaseolus vulgaris and the competitivity of an introduced Rhizobium strain: Effects of lime, mulch and repeated cropping. Soil Biology \& Biochemistry, Oxford, v. 19, p. 171-177, 1987.

RAMOS, M. L. G.; GORDON, A. J.; MINCHIN, F. R.; SPRENT, J. I.; PARSONS, R. Effect of water stress on nodule physiology and biochemistry of a drought tolerant cultivar of common bean (Phaseolus vulgaris L.). Annals of Botany, London, v. 83, p. 57-63, 1999. 
RAO, A. V.; VENKATESWARLU, B. Nitrogen fixation as influenced by water stress in selected crop legumes of the Indian arid zone. Arid Soil Research and Rehabilitation, London, v. 1, p. 89-96, 1987.

SAITO, S. M.; MONTANHEIRO, M. N.; VICTORIA, R. L.; REICHARDT, K. The effects of $\mathrm{N}$ fertilizer and soil moisture on the nodulation and growth of Phaseolus vulgaris. Journal of Agricultural Science, Cambridge, England, v. 103, p. 87-93, 1984.

SCHOLANDER, P. F.; HAMMEL, H. T.; BRADSTREET, E. D.; HEMMINGSEN, E. A. Sap pressure in vascular plants. Negative hydrostatic pressure can be measured on plants. Science, Washington, v. 148, p. 339-346, 1965.

SERRAJ, J. M. L.; FLEURAT-LESSARD, P.; JAILLARD, B.; DREVON, J. J. Structural changes in the inner-cortex cells of soybean root nodules are induced by short-term exposure to high salt or oxygen concentrations. Plant, Cell and Environment, Oxford, v. 18, p. 455-462, 1995.
SHERRIER, D. J.; VANDENBOSCH, K. A. Localization of repetitive proline-rich proteins in the extracellular matrix of pea root nodules. Protoplasma, Vienna, v. 183, p. 148-161, 1994

SUMMERFIELD, R. J.; HUXLEY, P. A.; MINCHIN, F. R. Plant husbandry and management techniques of growing grain legumes under simulated tropical conditions in controlled environments. Experimental Agriculture, Cambridge, England, v. 13, p. 81-92, 1977.

VANDENBOSCH, K. A.; RODGERS, L. R.; SHERRIER, D. J.; KISHINEVSKY, B. D. A peanut nodule lectin in infected cells and vacuoles and the extracellular matrix of nodule parenchyma. Plant Physiology, Baltimore, v. 104, p. 327-337, 1994.

WORRAL, V. S.; ROUGHLEY, R. J. The effect of moisture stress on infection of Trifolium subterraneum L. by Rhizobium trifolii Dang. Journal of Experimental Botany, London, v. 27, p. 1233-1241, 1976. 